\title{
The Effects of Social Factors on Police Interactions with Youth
}

\author{
Ryan Hankewich \\ Department of Sociology, MacEwan University
}

\begin{abstract}
It has been recognized, socially and legally, that youth require different treatment and methodologies by the criminal justice system compared to adults. As the first point of contact within the criminal justice system, police officers' perceptions of youth can have profound effects upon the youth they encounter. This paper critically reviews how these perceptions are formed and influenced by multiple levels of social factors. This analysis examines societal factors at the macro, meso, and micro levels, and how they influence police perceptions of youth, resulting police actions, and what level of police discretion they employ.
\end{abstract}

\section{Introduction}

The criminal justice system recognizes that, from their first interactions with police to the potential final outcome in the courts, youth require different approaches and procedures than those for adults. This analysis focuses on the first step of this process - interactions between youth and law enforcement. Law enforcement agencies are the metaphorical gate-keepers to the criminal justice system. When appropriate, police are empowered to use discretion to divert youth to alternative programs or services instead of the traditional criminal justice system.

However, police often lack the training required to exercise discretion in a productive manner. Kubiak, Shamrova, and Comartin (2019) explain that although police are likely the first responders, their limited training in human development and lack of information on community resources may result in more severe sanctioning than if they received more fulsome training (p.1). For example, minimally trained police would be more likely to use criminal charges rather than a more rehabilitative court diversion program. The lack of youth-focused training, along with societal impressions of rising youth crime rates, on-the-job experiences, and the additional requirements of the Youth Criminal Justice Act (YCJA), all contribute to how police professionally and personally perceive youth and can shape police perceptions of youth and how they should be treated, processed, and cared for in a law enforcement setting. This paper explores two related questions: What social factors influence police in their interactions with youth? How do they affect police use of discretion in deciding what is the appropriate course of action given the circumstances of the youth's actions?

How law enforcement officers and their respective police agencies perceive youth will have profound effects on the outcomes of police-youth interactions, including lasting implications for the youth throughout the processes and in future police interactions. These preconceived perceptions, along with the various societal influences that have shaped police officers view of youth, can be detrimental, beneficial, or mixed, to both police and youth during these interactions. As Brunson and Pegram (2018) note, most police interactions with youth occur in public and officers render decisions with little information about the youth's individual circumstances (p. 85). Therefore, police are relying almost completely on their preconceived perceptions when interacting with youth and exercising their discretion, as the decision is made essentially without considering individual factors for that specific young person. When individual characteristics are unknown or ignored, broad pre-existing perceptions easily take over, especially in the dynamic environment of policing, where split-second decisions are commonplace and necessary.

Despite lacking full information, police still consider and weigh all situational factors known to them at the time when interacting with youth and establishing their perception of the youth in that scenario. The societal factors that influence and form police perceptions of youth are entrenched at every 
level of society: macro, meso, and micro. These are formal and informal, external and internal factors that influence the discretion used by police in every interaction they have. Schulenberg (2009) explains that:

[s]ocio-legal theories of police behavior are concerned with the reaction of the police to the social structure of the situation. The structural view accounts for situational factors that are commonly distinguished as: (1) the nature and circumstances of the offense, and (2) the characteristics of the offender (p110).

The nature and circumstances of the offence are based largely in the macro and meso structures of society, while the characteristics of the offender are based in the micro with the one-on-one interactions between the youth and the officer. Each level contributes to the officer's perception of the youth and the resulting interaction.

\section{Macro Level Influences}

Macro level social factors are the social structures that provide governance to all of society. Law and legislation such as the Criminal Code of Canada (CCC), the Youth Criminal Justice Act, Controlled Drug and Substances Act, and the recently enacted Cannabis Act at the Federal level, as well as provincial legislation such as Gaming, Liquor and Cannabis Act, Traffic Safety Act, and numerous other statutes codify the legal powers that law enforcement agencies use to maintain social order. Police also retain many powers they held under the common law, also known as the ancillary power's doctrine ( $R v$ Godoy, [1999] 1 SCR 311 at para 12). The Supreme Court of Canada (SCC) outlines in $R v$ Dedman (1985), "The common law duties of police have been described as the preservation of the peace, the prevention of crime and the protection of life and property; (para.14)". Thus, police can act in certain ways to protect those interests that aren't codified in statutory law. For example, the power to search incident to arrest comes from the common law. The Supreme Court recently referred to it as:

"an ancient and venerable power. For centuries, it has proved to be an invaluable tool in the hands of the police. Perhaps more than any other search power, it is used by the police on a daily basis to detect, prevent, and solve crimes" ( $R v$ Saeed, 2016 SCC 24 at para 1).

The search incident to arrest can only be for "object[s] that may be a threat to the safety of the police, the accused or the public, or that may facilitate escape or act as evidence against the accused" (Cloutier c Langlois, [1990] 1 SCR 158 at para 62). Therefore, if police perceive youth to be violent or likely to carry weapons, they are more likely to use this common law power and search youth incident to arrest - both subjecting youth to a more intrusive search than may be necessary and opening youth up to discovery of other prohibited items that might otherwise have gone unnoticed. Therefore, when police are interacting with youth, they must do so within the confines of the powers and limits placed on them through various types of laws. "Far more important, however, is the social and legal, and indeed, political, principle upon which our criminal law is based, namely, the right of an individual to be left alone, to be free of private or public restraint, save as the law provides otherwise" $(R v$ Dedman 19852 SCR 2 at para 12). While police have discretion, their discretion is limited based upon what they are legally allowed to do. The options legally given to police when dealing with a young person impact both police's perception of youth and how police exercise their discretion.

Ricciardelli and colleagues (2017) reviewed the YCJA and noted that, prior to its implementation, police would regularly use formal sanctions (criminal charges) in many cases where alternative measures or another diversion program would have been more appropriate. These changes brought by the implementation of the YCJA were made as Canada had one of the highest youth incarceration rates in western countries (Ricciardelli et al., 2017). The YCJA changed police perceptions of youth through formal, national legislation that modified police discretion to require police to always consider alternatives to formal sanctions first (except in cases of the most serious crimes), and to exhaust all options before laying a criminal charge. As all enforcement is dealt with at the provincial level, this can sometimes create further influences on police interactions with youth as every province and territory is unique in its diversion programing, program availability, and general desire to defer youth from formal sanctions.

Canada is a vast country - the second largest country by land mass - which brings unique challenges to police agencies that police urban, suburban, and rural

communities. Geography can have profound impacts on police discretion, as police may be limited in the judicial or diversionary options they have based on the environment (e.g., urban versus remote rural) and the province in which they police (Ricciardelli et al., 2017; Schulenberg, 2009). Schulenberg's (2009) research shows that policing action can be heavily dependent on community-type and other geographically rooted considerations. This is confirmed by Ricciardelli and colleagues (2017), who outlined that Quebec did not even adopt the YCJA and kept their previous laws governing youth crime. This would create a very different perception of youth for police officers in Quebec compared to British Columbia, which had the highest level of compliance to the provisions of the $Y C J A$ regarding court diversionary programs. 
The Supreme Court of Canada (SCC) has also influenced police interactions in both allowing police discretion and expressing for its need in order for the criminal justice system to function effectively. In R. v Beare (1988) the SCC stated:

"the existence of the discretion conferred by the statutory provisions does not, in my view, offend principles of fundamental justice. Discretion is an essential feature of the criminal justice system. A system that attempted to eliminate discretion would be unworkably complex and rigid. Police necessarily exercise discretion in deciding when to lay charges, to arrest and to conduct incidental searches. (para. $51)^{\prime \prime}$

These macro level social factors have profound implications on what actions are available to officers in their interactions with youth - they can empower officers to take action or limit officers' options when it may be legally impermissible, despite being in the public interest. The use of police discretion must still be exercised on a reasonable basis and within the confines of the law or it could be struck down by the courts. Discretionary powers are intended to be used by police officers to ensure that not every offender is met with the full blunt force of the law, but that other options which may better satisfy the ends of justice can be considered and utilized when appropriate. The exercises of discretion while essential are still subject to challenge as violations of the Canadian Charter of Rights and Freedoms if they are done improperly or with improper motives, for example, racism.

\section{Meso Level Influences}

Meso level influences come from the communities, groups, agencies, and organizations within the areas where police work. This level of influence can come from the police agencies themselves, such as internal policies requiring arrests for domestic abuse offenders. Community police initiatives have been widely pursued in jurisdictions across North America and are being implemented in other countries. This includes Ukraine, under the European Union Advisory Mission (EUAM), which believes that community policing should treat "members of the public as customers that have needs to be met, accompanied by a willingness to listen to and act upon public opinion regarding policing priorities". These types of initiatives and agency mandates create additional influences on police perceptions of youth, and how police use their discretion in their interactions with young people. This implementation of community policing has been an effective tool in empowering citizens to work with police to determine what their needs are, how to meet those needs, and who should be responsible for meeting those needs. Community policing, in building and establishing the partnerships with the community, brings about perceptions of police legitimacy in that the police are seen and embraced by the community which they serve.

Another meso level influence that affects police interactions with youth is the young person's family. According to Schulenberg's (2009) analysis of Black's Theory of Law, youth with less informal social control from family and community are more likely to receive more formal social control from the law. Thus, if a youth does not have a strong family or community support to provide the discipline the officer believes he deserves, the officer will use a formal sanction to ensure the discipline is being applied. Similarly, Guzman and Kim (2016) assert that unique environments and locations directly affect the methods of policing that are developed and implemented in these areas. Specifically, Guzman \& Kim (2016) suggest that in communities with low levels of crime, police typically use more traditional formal levels of control; in contrast, in communities with higher levels of crime, police rely on different influences on their discretion. For example, in Schulenberg's (2009) research a police officer explained that he was working in a small rural community that did not want youth to have criminal records, attend court, and/or to be taken away; they wanted the children to remain in the community. The community wanted youth deferred to restorative justice programs, despite the officer's belief that he had pushed the limits of the informal sanction to make that happen, and despite his own belief that formal sanctions (criminal charges) were more appropriate. This particular officer had to look at the circumstances outside of his interaction with that specific individual, which influenced his decision on what type of action to take. His decision could have fractured community relationships with the police, delegitimized police, or not met the requirement of social order or deterrence for future behaviour of the youth. His perceptions of the community, and those imposed on him by the community, had to shape his perceptions of youth. The interactions between police and youth are governed not just by law, but also by community expectations and influences that guide the police officer's actions.

\section{Micro Level Influences}

Police are human beings from varied backgrounds, ages, cultures, ethnicities, socioeconomic backgrounds, and belief systems, all of which impact an officer's personality. The most widely used diagnostic tool in North America to assess personality traits of police applicants is the Minnesota Multiphasic Personality Inventory (MMPI), which identifies the characteristics of ideal police applicants. Kitaeff's (2011) Handbook of Police Psychology noted that police tend to score within the normal range on the MMPI clinical scales, but lower than the general population on neuroticism (p. 427). Kitaeff (2011) also noted that successful police 
applicants score higher in two other areas of the MMPI: the $\mathrm{K}$ scale (defensiveness) and the Hy Scale (hysteria). The K measures defensiveness, but reflects the applicants desire and ability to present themselves favourably. The Hy Scale contains items that suggest the applicant is well socialized and well adjusted, in addition to other items. This is consistent with additional research showing that higher scores in $\mathrm{K}$ and $\mathrm{Hy}$ are indicative of desirable qualities among professional job applicants. These desirable qualities include lower levels of neuroticism and the ability to present oneself favourably; from a police organizational standpoint, these applicants tend to have higher rates of success and longevity with the police service. These qualities are influential in police officer's interactions with all persons they encounter, including youth.

The officer's level of work experience, background, geographic location, and the demeanor of the youth(s) are all micro level influences on a police officer's level of discretion. In a study of police in New York City, officers' perceptions of themselves were evaluated based on the rates of violence in the areas where they worked. Kitaef's (2011) analysis indicated that officers in areas of higher violence perceived themselves as less accommodating and less submissive then those in areas with lower violence. However, police did not use any additional authoritative power in the higher violence versus lower violence areas. This is an isolated study of one police service in one area of the United States, but still provides some interesting insights to the micro level influences that influence officers. Police in the higher crime areas were more assertive, but did not exercise more authoritative power, because the police selection process finds people that are able to adapt their responses to the situation without an abuse of power. Therefore, where police perceive youth to be more violent, they may be more assertive with those young people, without resorting to abuses of power.

When taking into account the interaction between different levels of social factors, Schulenberg (2009) identified four specific factors that affected police levels of discretion: legal factors of offense seriousness, degree of harm, presence of a weapon, and the youth's prior record (p.114). These factors come from all levels, from the macro (legal factors), to the meso (degree of harm), to the micro (youth's prior record; use of a weapon). Police perceptions of the individual are also based on the youth's behaviour and interactions with the officer. The officer assesses the youth's demeanor, signs of alcohol or drug use, and indications of a medical or mental health condition. Although the officer's assessments could be identified as youth-specific training, it is general training that is provided to police during their initial training and varies from police service to police service.
The extent of youth-focused training and experience with young people are also key influences on officers' perceptions of youth. As Kubiak, Shamrova, and Comartin (2019) explain, youth experience behavioural, cognitive, social, emotional, and physical changes during adolescence. This, compounded by the lack of police training in human development and mental health, can make interactions with youth volatile and negative to both officer and youth alike. This lack of knowledge and awareness of the specifics of human development can lead to ineffective or improper courses of action, such as overreaction by the officer, or imposing a formal sanction that has far-reaching consequences when an informal sanction would have been the better option for the individual.

\section{Conclusion}

Law enforcement is not a straightforward process, but rather is influenced by various levels within the social structure. Social factors have profound effects on police and how they assess, process, and execute their duties when they interact with and observe youth. The factors at the macro level are generally the same across Canada, as all police powers outside of common law are governed by various federal acts including the Criminal Code of Canada. But these powers do vary slightly when considering the Youth Criminal Justice Act, as this act has been implemented differently and to varying degrees by the provinces. The meso level structures are more specific to the community in which the officer works and can have a strong bearing on how that officer perceives youth and uses discretion in the interactions with young people. A specific police service's directives and policies influence officers' perceptions and available courses of action. Finally, the micro level displays the most profound influences, as no two police officers are the same. Each officer brings his or her own unique history, skills, knowledge, professional, and personal experiences to the situation with that youth. This can have profound outcomes for the officer and youth alike, both positive and negative. An area of research that was noted to be missing was police officers with children and how that may influence their perceptions of youth. It seems logical that this potential micro level influence could bring strong bearing to an officer's perceptions of and reactions to youth. Police perceptions of youth are dictated and formed by all levels of social structure. These influences also come from of societal pressure, community and personal beliefs as they evolve overtime. Growing research around youth criminality, police interactions with youth, youth deviance, and deterrence will continue to shape and influence social structures, and in turn police perceptions and discretion of youth. 


\section{References}

Beare $v R$, [1988] 2 SCR 387, 55 DLR $\left(4^{\text {th }}\right) 481$ (SCC).

Brunson, R. K. \& Pegram, K. (2018) Kids do not so much make trouble, they are trouble: Police-youth relations. The Future of Children, 28(1), 83-102.

Cloutier c Langlois, [1990] 1 SCR 158, 30 QAC 241 (SCC).

De Guzman, M. C. and Kim. M. (2016) Community hierarchy of needs and policing models: Toward a new theory of police organizational behavior." Police Practice and Research, 18(4), 352365 .

European Union Advisor Mission Ukraine. (n. d.). Our Priorities CommunityPolicing. Retrieved from http://www.euamukraine.eu/our-mission/our-priorities/community-policing/

Hilal, S., Densley, J. A., \& Jones, D. S. (2017). A Signalling theory of Law Enforcement Hiring. Policing and Society, 27(5). DOI: 10.1080/10439463.2015.1081388)

Kitaeff, J. (Ed.). (2011). Handbook of police psychology. New York, NY: Routledge.

Kubiak, S., Shamrova, D., \& Comartin, E. (2019). Enhancing knowledge of adolescent mental health among law enforcement: Implementing youth-focused crisis intervention team training. Evaluation and Program Planning, 73, 44-52.

Ricciardelli, R., Crichton, H., Swiss, L., Spencer, D. C., \& Adorjan, M. (2017). From knowledge to action? The Youth Criminal Justice Act and use of extrajudicial measures in youth policing. Police Practice and Research, 18(6).

DOI:10.1080/15614263.2017.1363971

$R v$ Deadman, [1985] 2 SCR 2, 20 DLR $\left(4^{\text {th }}\right) 321$ (SCC).

$R v$ Saeed, 2016 SCC 24, [2016] 1 SCR 518 (SCC).

Schulenberg, J. L. (2009). Patterns in police decision-making with youth: An application of Black's theory of law. Crime Law Soc Change, 53,109-129. DOI:10.1007/s10611-009-9210-4). 